\title{
AIM OF USING CULTURAL ELEMENTS IN A LANGUAGE CLASS TO ENHANCE STUDENTS' SPEAKING ON BASIS OF ACQUISITION AND SKILL
}

\author{
Pelin Hamurabi Sözen \\ Ma Ed., Baskent University, TURKEY, phamurabi@hotmail.com
}

\begin{abstract}
Learning a new language as a foreign language rather than a second language is not very easy. Since the learner is alone this new world, (s) he may need effort to overcome the barriers of language acquisition. The natural environment of a learner may not include social, emotional, pedagogical or even cultural support. Socially, the learner may not have a peer group who speaks the target language or a parental support and may not have a clear idea about the attitude towards language and learning as well. In pedagogical sense, the school and classroom culture, improper materials and curriculum or method of instruction, strategies as well as little access to input can lack the supportive learning environment. In emotional basis, the learner's self-belief and motivation can be low. There can be many items which result in resistance for a learner in case of a language acquisition. Every learner needs encouragement. Life without knowing a foreign language seems almost inescapable. People live in world where mobility is in the heart of many activities. This idea is valid for educational and business life. One can be mobile either by travelling or technology. In both means, there is a need for not only the language but also the cultural elements which are more vivid in a language. In this sense, curriculum is the core. It serves as a framework. Appropriate changes should be done in class depending on your students' needs.

This research aims at finding the needs of approximately 400 university students who are learning English as a foreign language. In this research, the link between cultural elements in a curriculum and acquisition of speaking skill which has a prior place among students is also studied.
\end{abstract}

Keywords: Multiculturalism, curriculum, Common European Framework, communication, cultural elements in a language class.

\section{INTRODUCTION}

Language competency, as has always been, is one of the prior needs in our globalized world. In this world where the knowledge is transformed and transferred quickly, one should learn a foreign language so as to cope with this rapid change. In this sense, language learning is vital on personal basis, but at the same time the world needs societies where people overcome this challenge. As mentioned by OECD (2016) , language learning is not only a means of improved communication, but more importantly it plays a key role in prompting global understanding and respecting cultural differences. 
Language is system of sounds, mimics and writings where people of a society communicate with each other (Brown, 2005). In other words communication is in the core of language. There is a proverb in Turkish as; one language one person who tries to exemplifies the importance of not only the language itself but also the culture behind of it. When a language is learnt one should take culture into consideration as well. Durant and Shephard (2009) emphasized that, there are so many questions that arise on people's mind about the purpose and adaptation of culture. At the same time, there is another issue like, how people react to such cases in societies.

People learn a new language for many different needs. The reasons may differ, but the use of language leads the person to communication and this needs at least a certain amount of cultural knowledge. Without this proper information about the newly learnt language, the learner should be lost in translation. As Demirel (1993:4) mentions the most effective way of communication among people is language. This shows that, if language is used as a mean of communication, it has a social function and a role to bond the society and its culture. In other words, communication is not just for sharing our ideas and feelings but also the culture. Therefore, during the language acquisition period, the learner should learn the culture of this new language so as to avoid any personal misunderstandings.

People are shaped by the culture they are surrounded and this understanding affects the people and their language (Leveridge 2008). That is to say, it is inescapable to see culture, language and communication as a whole.

Linguistic competence is not enough to survive in this new world. If you communicate with someone in a foreign language you should at least have a general idea about specific cultural elements. These references can be from geography, history, occupations, free time activities or even formal and informal addressing (Neff and Rucynski 2013). Neither a language nor a society is isolated in the universe. People share the same world so in order to avoid misconceptions it would be better to pay attention to cultural elements.

Each person in a family and each family in a society as well as each group in an institution is linked to one another and affected from each other. What lies beneath this linkage has always been a research topic for anthropologists. In a societal environment, everything is linked with each other by human beings and that is called communication (Güvenç, 1997a; 47).

As Lightbrown and Spada (2006) mentions the importance of Vygotsky and his sociocultural theory, which says that conversations occur through the social interaction; people find a place for what they have learnt before during social activities. They express themselves, ask questions and try to convey a message.

Each step in learning needs awareness. Otherwise it may be hard to reach a specific goal. As Akpınar and Öztürk (2009) claims, the main aim of multicultural education is to raise awareness and understanding of other cultures so that children will learn language free from misconceptions. There is a simple sample about the lack of cultural competence. The author who works at an English school in Japan wanted to say "see you later" in Japanese when leaving school but he chose different words which were grammatically correct, but culturally not. A Japanese worker usually prefers to say words which refer to "excuse me for leaving before you" (Neff and Rucynski 2013).

Communication is an effective method to reach information. The purpose of education is to convey this information. Having relationships using a language, conveying thoughts and feeling are the foremost function of a language. This is not just valid on personal basis. People from different countries communicate. Today's world gives people chance to be mobile in many different ways. During this journey people are face to face with many cultures. Demircan (2002:22) claims that people of this era are multicultural so traditional ways of education which crabs only one culture should not be enough instead there should a teaching method which is multicultural too.

In recent years, sociologists claim that it is not enough to describe the nature of language only by performance and competence as Noam Chomsky argues since there is a need for third dimension called communicative competence (Demirel, 1993:43). In this approach language is not just set of rules. It is a vehicle to communicate. If a person can communicate, then it means this person learnt that language. So the classroom activities should be designed in such a way that learners can talk to each other and express themselves rather than memorizing certain things. The function of the teacher here is to create a classroom setting suitable for this aim.

When people talk to each other, they not just talk but at the same time they share ideas. They represent themselves as a part of a social group like teacher-student, employer-employee. In other words social identities are an important part of communication. Communicative competence expresses that it is not enough to learn the linguistic rules to become aware of these different identifications in communication 
(Council of Europe, 2002a;9).

Council of Europe has been working on European languages, understanding of different cultures, language teaching programs in various countries, certification of competencies that enables the mobility of learners for many decades. These competencies mostly depend on cultural elements. In order to combine all its programs under one single framework, a study is compiled and its final version is published in 2001 by Cambridge University which is called Common European Framework (Council of Europe 2002b;1).

Common European Framework views multiculturalism and multilingualism as a way of life. Learning a language and its culture at the same time is the direct way to lead such a life. However, learners are expected to have some qualifications under these circumstances. These are grouped under such headings (Council of Europe 2001:11-15):

- General Competencies

- Communicative Competencies

- Language Activities

- Areas

According to Common European Framework (Council of Europe, 2002a; 10) social and national identities are supplementary components of communication. A learner, who is willing to have a meaningful intercultural relation, is a person who knows the rules, values, norms of the target culture. In this sense, a good teacher is someone who can show the difference between two cultures; create an intriguing atmosphere in class. The students of such a teacher know how they are seen from the perspective of target culture.

Common European Framework also states few points to help the learner in this process (Council of Europe, 2002a; 12-13). These are:

- Intercultural Attitudes

- Knowledge

- Skills of interpreting and relating

- Skills of discovery and interaction

- Critical cultural awareness

There are two aims in language teaching. First one is to teach students how to learn a language and second one is to raise a level of understanding towards language and culture (Gromann, 2003; 44). It is not very easy to accomplish all these. However, a curriculum composed of relevant topics and a well-equipped teacher can handle this situation. Leveridge (2008) highlights that teachers should teach the cultural background of language otherwise it would be meaningless to teach a language. According to him the purpose of learning a language is a whole only if the learner uses it in an appropriate cultural context.

In traditional learning-teaching cycle, societies are usually surrounded by their limitations. Learners are passive in education systems, but in this new world where there are no limitations to reach information and other societies, learners may be anxious about learning global aspects. They should be in search of reaching as much information as they can to be a part of this era. Learners are more active when they try to learn not only their language and culture but also others. Coşkun (1997) describes the differences between traditional and global learning as he has taken from Graf and Zumsteg (1995:27)

Traditional Learning

Global Learning

\begin{tabular}{|l|l|}
\hline a) World aspect is only limited to local & a) A global world aspect \\
\hline b) A geographical perception from near to far & b) Having a link between local and global \\
\hline $\begin{array}{l}\text { c) Far from the experiences of people in other } \\
\text { parts of the world }\end{array}$ & $\begin{array}{l}\text { c) Not far from the experiences of people in other } \\
\text { parts of the world }\end{array}$ \\
\hline $\begin{array}{l}\text { d) Knowledge is transferred only through its } \\
\text { subsections }\end{array}$ & $\begin{array}{l}\text { d) Transferring knowledge by linking ideas is } \\
\text { encouraged }\end{array}$ \\
\hline e) Learner is passive & e) Learner is active \\
\hline f) There is an estimated abstraction & f) Experiences of the learners \\
\hline g) Rationalism is in the foreground & $\begin{array}{l}\text { g) Collaboration and cooperation is in the } \\
\text { foreground }\end{array}$ \\
\hline
\end{tabular}

There is a strong bond between school and culture since culture is not a simple factor. Culture is in 
everything people say, think and act. Therefore, schools are responsible for this cultural formation and teachers are in charge to reach this aim (Spindler 1994, 2).

\section{METHODOLOGY}

The purpose of this study is to evaluate the curriculum of English preparatory school of a private university. The curriculum is evaluated according to the multiculturalism criteria described by Council of Europe in Common European Framework. In this regard, the study focuses on students' attitude towards the culture of target language.

The study has relational scanning model. The universe of the study is language instructors and senior students are the subjects of this research. Their ideas about the program are asked. These ideas are compared to the standards of cultural elements that need to be found in a multicultural curriculum. In addition, it is thought that these learners will mostly have oral communication as a result of increased mobility and European Union education programs. What they need will be communicative competence in this sense. At this stage, it is thought that students will most probably use their communicative skills at the campus and public areas so as a research area, holidays, festivals and ways of congratulating are chosen as cultural elements. 380 senior students and 184 instructors are in the cluster sampling of the study.

Both qualitative and quantitative approaches are used. Qualitative data is gathered via classroom observations, interviews and exploration of the documents such as, textbooks, materials, annual plans and projects. Quantitative data is gathered via a morale survey. Likert type rating scale is used in the survey. Two different surveys are distributed to teachers and students. One of the surveys includes questions whether there are cultural elements in the curriculum. Both the teachers and students answered this survey. The other survey is given only to students and questions are asked to measure their attitude towards cultural elements in language learning.

\section{FINDINGS}

The findings mentioned here are only some of the results which belong to the relation between cultural elements and students' speaking skills. According to the qualitative data results of the study, cultural elements about holidays and festivals are mostly found in general English textbooks which are used in preparatory classes. These elements are not only about British cultural points. It is easy to see $m$ any items describing different cultures since it is clear that multiculturalism and multilingualism is part of our world.

Language instructors have certain ideas about the students' attitude towards cultural competence. Their views can be classified under three groups:

- The first group had thought senior classes. They stated that their students are aware of the cultural facts and differences. This group wants to be equipped with more cultural information and to achieve this they not only attend the classes but also listen to music, surf the internet or watch films that belong to target language.

- Second group of instructors had thought freshman and sophomore. They stated that their students are not aware of multiculturalism. They are prejudiced as well.

- Third group of instructors are the ones who had thought translation classes. Their textbook does not contain cultural elements.

In quantitative part of the study, in addition to the survey that is about curriculum evaluation, another survey is distributed to the students. The second survey asks questions about their attitudes to target culture. The result of this survey has subsidiary findings.

- $59.8 \%$ of the students want to learn more about target culture. They say that cultural competence may help them to be better in language competence.

- $40.2 \%$ of the students want to learn more that is needed as the course requirement. This is parallel with the findings gathered from the interviews done with the instructors.

- $65.3 \%$ of the students are glad to study cultural differences.

- $70.1 \%$ of the seniors say that having a cultural background, knowing the differences would make communication easier.

- $41.1 \%$ of the students say that learning cultural difference would motivate them.

- $69.5 \%$ of the students do not agree that learning cultural differences would be meaningless outside 
the classroom.

\section{DISCUSSIONS}

Common European Framework emphasizes the importance and need for multiculturalism and multilingualism. Since the importance finds a meaning when this idea is shared and used, the benefits of communication in other words the capability to speak a foreign language has a higher place in this period.

As it is gathered from the information obtained by literature review, students should learn these cultural elements not in a separate hour of teaching. It should be integrated into curriculum. Council of Europe highlights how knowing cultural elements can give comfort to the learner about speaking skills. So both the curriculum and evaluation stages should include these two items. To achieve this, there can be a training program. In this training, how to deal with possible problems in class, what should be and how it should be thought can be planned.

\section{REFERENCE LIST}

Akpınar K. D. and Öztürk M. S. (Yaz 2009) EKEV AKADEMi DERGiSi Yıl: 13 Sayı: 40

Brown, H. D. (2000) Principles of Language Learning and Teaching (4 ${ }^{\text {th }}$ edition). New York: Pearson Education.

Coşkun, H. (1997) Kültürlerarası Eğitim. Ankara:Hacettepe Taş.

Council of Europe, (2001) Common European Framework of Reference for Languages: Learning, teaching, assessment. Cambridge. Cambridge University Press.

Council of Europe, (2002a) Developing the Intercultural Dimensions in Language Teaching. A Practical Introduction for Teachers. Strasbourg:Modern Languages

Council of Europe, (2002b) Common European Framework of Reference for Languages:Learning, teaching, assessment: Case Studies Strasbourg: Cedex

Demircan, Ö. (2002). Yabancı Dil Öğretim Yöntemleri. İstanbul:DER Yayınları.

Demirel, Ö. (1993) Yabancı Dil Öğretimi: Illkeler, Yöntemler, Teknikler. Ankara: Usem Yayınları

Durant A, Shepherd I, European Journal of English Studies Vol. 13, No. 2,August 2009, pp147-:162

Güvenç, B. (1997a) Kültürün abc'si. İstanbul: Yapı Kredi Kültür ve Sanat Yayıncılık.

Leveridge A. N. 2008. The Relationship Between Language \& Culture and the Implications for Language Teaching. TEFL.net: TEFL Articles From <http:www.edition.tefl.net/articles/teacher-tecnique/languageculture> (Retrieved on 08.4.2016)

Lightbrown P. M., Spada N. 2006 How Languages are Learned. Oxford University Press.

Neff P. and Rucynski Jr. J 2013 English Teaching Forum, Number 2

OECD- EDUCERI: Languages in a Global World: Learning for Better Cultural Understanding. From <http:/www.oecd.org/edu/ceri/50086216.pdf> (Retrieved on 11.4.2016)

Spindler G. \& L. (Eds). (1994) .Pathways to Cultural Analysis. California: Sage Publications. 